\title{
PERHITUNGAN VOLUME CADANGAN BAHAN GALIAN TAMBANG ANDESIT MENGGUNAKAN METODE RESISTIVITAS DIPOL-DIPOL DAN INTERPOLASI 3D DI LAPANGAN "A"
}

\author{
Ade Rama Tanjung Putra ${ }^{\text {a) }}$, Agus Riyanto \\ Departemen Fisika, Fakultas Matematika dan Ilmu Pengetahuan Alam, Universitas Indonesia \\ Email: a)aderamay2@gmail.com
}

\begin{abstract}
Abstrak
Pertumbuhan ekonomi dan gencarnya pembangunan infrastruktur secara nasional menyebakan kebutuhan bahan bangunan meningkat, termasuk Batuan Andesit. Batuan Andesit banyak dimanfaatkan untuk pembentukan pondasi bangunan, pembuatan jembatan serta pengaspalan jalan. Meskipun demikian, data BPS 2013-2015 menunjukkan bahwa peningkatan kebutuhan Batuan Andesit justru disertai dengan penurunan jumlah pengusaha batu andesit serta penurunan volume produksi batu andesit. Untuk menjamin keberlanjutan proses pembangunan nasional, perlu dilakukan pencarian cadangan Batuan Andesit baru. Survei geolistrik resistivitas telah dilakukan dengan 15 lintasan di lokasi "A" Provinsi Gorontalo. Data resistivitas semu yang diperoleh diolah menjadi model dua dimensi melalui inversi linear menggunakan perangkat lunak RES2DINV. Model dua dimensi selanjutnya diinterpolasi menggunakan perangkat Rockworks15 menjadi model tiga dimensi. Analisa model dua dimensi dan tiga dimensi menunjukkan adanya cadangan Batuan Andesit di lokasi "A" dengan batas

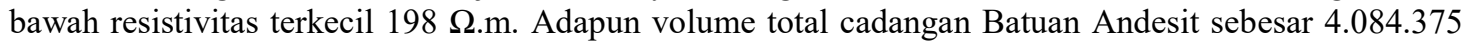
$\mathrm{m}^{3}$. Hasil ini menunjukkan bahwa Gorontalo berpotensi menjadi penyedia Batuan Andesit untuk menyokong proses pembangunan lokal di sekitarnya.
\end{abstract}

Kata-kata kunci: Batuan Andesit, Metode Dipol-dipol, RES2DINV, Rockworks, Survei Resistivitas

\begin{abstract}
The economic growth and infrastructure development on national scale in Indonesia have caused the demand of building material increased, including andesitic rocks. Andesitic rocks have been utilized for creating building foundation, bridge development as well as road paving. Regardless, according to BPS data from 2013-2015 during these growth, the number of andesitic rocks businesses and mining were decreased. Therefore, to ensure the continuation of national development, an exploration of new andesitic rocks mine is required. Geo-electrical resistivity survey with 15 survey lines has been done at location "A", Gorontalo Province. The apparent resistivity data acquired have been processed into twodimensional model through linear inversion using software RES2DINV. This two-dimensional models were further interpolated and extrapolated using software Rockworks 15 to into three-dimensional model. Analysis of these models shows a potential andesitic rocks reserves at location "A" with minimum lower cut-off resistivity is $198 \Omega . \mathrm{m}$. The total reserve volume ranging $4.084 .375 \mathrm{~m}^{3}$. This result implies that Gorontalo can be a supplier of andesitic rocks to support local development.
\end{abstract}

Keywords: Andesitic rocks, Dipole-Dipole Method, RES2DINV, Rockworks, Resistivity Survey 


\section{PENDAHULUAN}

Berdasarkan permasalahan diatas, maka solusi yang dapat ditempuh adalah memaksimalkan produksi perusahaan yang masih aktif dengan cara menghitung sumber volume pada lapangan tambang baru dan ataupun menghitung kembali potensi volume cadangan bahan galian tambang andesit yang sudah ada pada masing-masing perusahaan. Salah satu metode geofisika yang dapat mengetahui potensi volume cadangan bahan galian tambang adalah metode geolistrik. Namun, berdasarkan data Badan Pusat Statistik, volume produksi pertambangan bahan galian komoditas andesit terus mengalami penurunan sejak tahun 2013 yang ditampilkan pada GAMBAR 2. Selain itu, terjadi pula penurunan jumlah perusahaan yang memproduksi bahan galian andesit sejak tahun 2013 yang ditampilkan pada GAMBAR 3 (Nuryati dan Faradila, 2016), dan diproyeksikan akan terus menurun. Berdasarkan permasalahan diatas, maka solusi yang dapat ditempuh adalah memaksimalkan produksi perusahaan yang masih aktif dengan cara menghitung sumber volume pada lapangan tambang baru dan ataupun menghitung kembali potensi volume cadangan bahan galian tambang andesit yang sudah ada pada masing-masing perusahaan. Salah satu metode geofisika yang dapat mengetahui potensi volume cadangan bahan galian tambang adalah metode resistivitas.

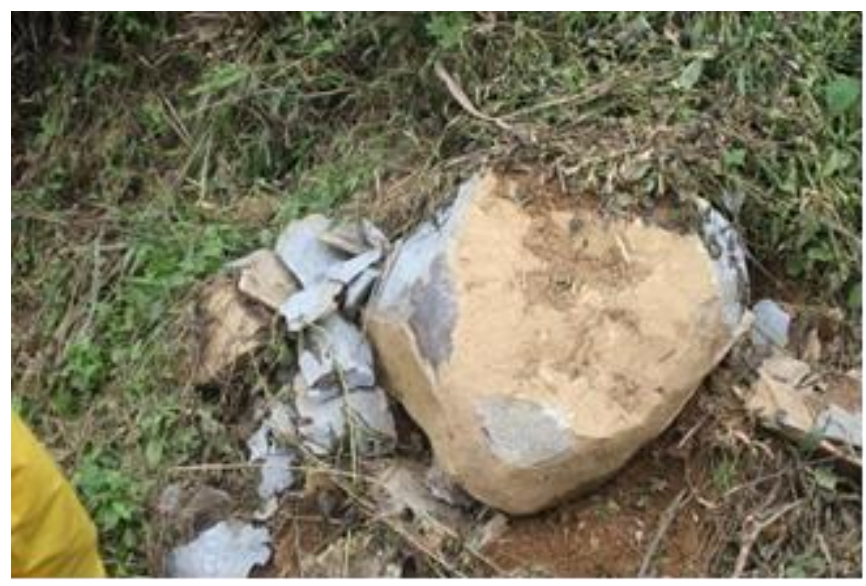

GAMBAR 1. Batuan Andesit

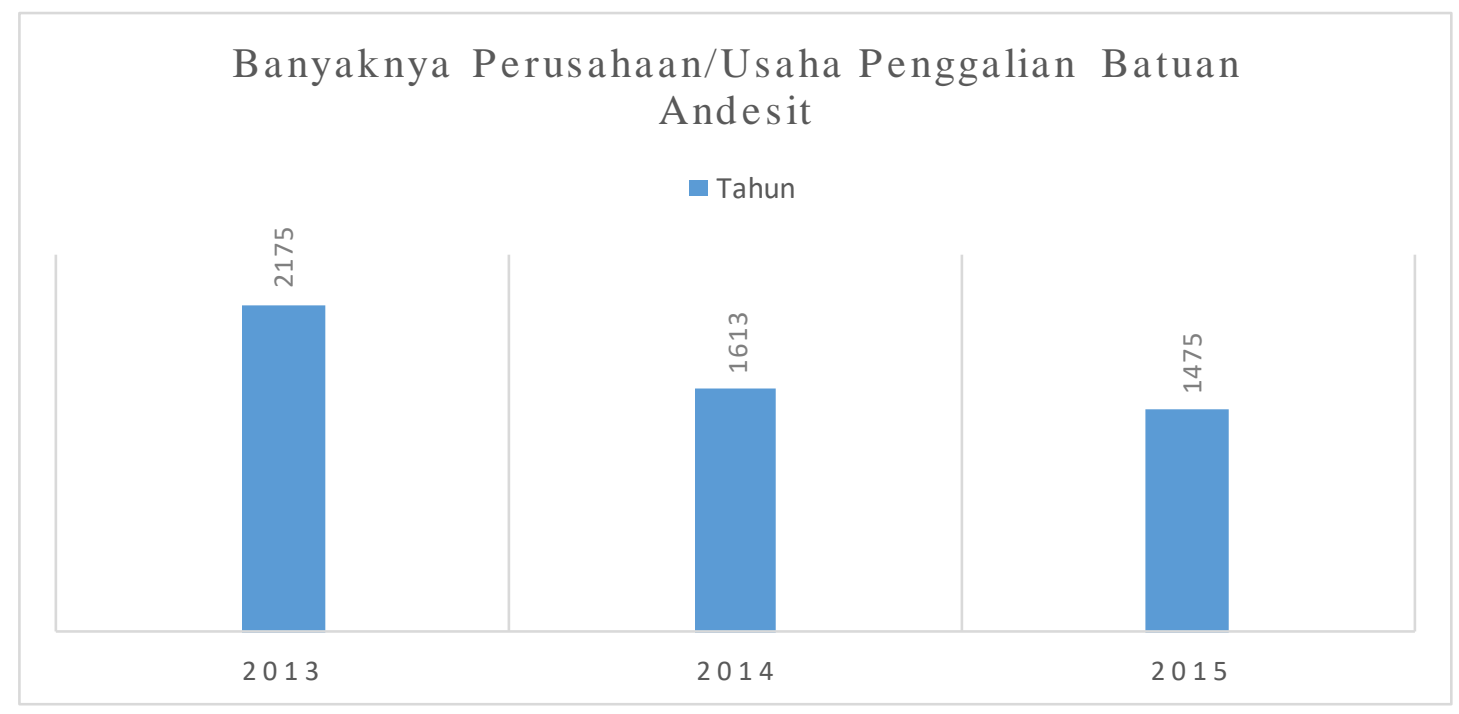

GAMBAR 2. Grafik penurunan jumlah perusahaan/usaha penggalian Batuan Andesit (Nuryati dan Faradila, 2016) 




GAMBAR 3. Grafik penurunan jumlah volume produksi perusahaan/usaha penggalian Batuan Andesit (Nuryati dan Faradila, 2016)

Metode geolistrik atau disebut juga metode resistivitas yaitu salah satu metode geofisika yang memanfaatkan aliran listrik untuk mengetahui sifat aliran listrik di dalam batuan di bawah permukaan bumi (Santoso, 2002). Metode ini biasanya digunakan untuk eksplorasi air tanah, namun juga dapat digunakan untuk mencari lokasi patahan, dan eksplorasi mineral dalam tanah dan arkeologi (Reynold, 1997). Analisis batuan tambang spesifik dapat dicari dengan berdasarkan pada kenyataan bahwa batuan/mineral mempunyai nilai resistivitas yang berbeda-beda ketika dialiri arus listrik. Nilai resistivitas merupakan kemampuan suatu benda atau batuan untuk melewati arus listrik. Jika batuan sukar dalam mengaliri arus listrik, maka semakin besar nilai resistivitas batuan tersebut (Suyanto dan Utomo, 2014).

\section{BATUAN ANDESIT}

Nama andesit diambil dari pegunungan Andes, yakni sebuah lokasi di Amerika Selatan, di mana banyak Batuan Andesit ditemukan. Berdasarkan proses pembentukannya, Batuan Andesit dikategorikan sebagai batuan beku ekstrusif yang memiliki kandungan silicon dioksida 57-63\% (Blatt, Harvey, dan Robert J. Tracy, 1996). Warna batu andesit umumnya bervariasi dari abu-abu terang hingga abu-abu gelap (GAMBAR 1).

Batuan Andesit terbentuk dari pembekuan lava pada suhu $800-1000^{\circ} \mathrm{C}$. Magma andesitik memiliki viskositas tinggi dengan kandungan gas yang tinggi pula, sehingga ketika terjadi fenomena geologis seperti erupsi volkanik atau pelelehan lapisan batuan akibat gerakan lampeng bumi,. magma andesitik cenderung keluar permukaan dan kemudian membeku. Umumnya magma andesitik berasal dari pelelehan batuan basaltik di area subduksi ketika terjadi pergesekan akibat kekuatan tektonik.

Selain itu, Batuan Andesit juga umum ditemukan di pegunungan strato sebagai hasil erupsi. Batuan Andesit dari gunung strato banyak ditemukan di Amerika tengah, Meksiko, Washington, Oregon, Jepang, Filipina, Selandia Baru, serta Indonesia. Batu andesit banyak dimanfaatkan terutama sebagai bahan konstruksi untuk mendukung proses pembangunan infrastruktur yang sedang dikembangkan di Indonesia

\section{KONDISI GEOGRAFIS GORONTALO}

Provinsi Gorontalo merupakan provinsi ke-32 di Indonesia yang diresmikan pada tanggal 5 Desember 2000 berdasarkan Undang-Undang RI Nomor 38 Tahun 2000 (hasil pemekaran dari 
Provinsi Sulawesi Utara). Provinsi ini terletak pada latitude $0019^{\prime} 00^{\prime \prime}-0057^{\prime} 00^{\prime \prime}$ LU dan longitude 1210 23' 00" - 1250 14' 00" BT. Provinsi ini terbagi atas lima kabupaten dan satu kota, yaitu Kabupaten Boalemo, Kabupaten Gorontalo, Kabupaten Pohuwato, Kabupaten Bolango, Kabupaten Gorontalo Utara, dan Kota Gorontalo. Luas provinsi ini sekitar 12.435,00 km2 dengan jumlah penduduk sebanyak 1.133.237 jiwa pada tahun 2016. Letak provinsi ini diapit oleh dua perairan, yaitu Teluk Gorontalo disebelah selatan dan Laut Sulawesi di sebelah utara, serta diapit oleh dua provinsi, yaitu Provinsi Sulawesi Tengah di sebelah barat dan Provinsi Sulawesi Utara di sebelah timur (BPS, 2018).

Secara fisiografis, Pulau Sulawesi merupakan wilayah pertemuan tiga lempeng, yaitu Lempeng Eurasia, Lempeng Pasifik, dan Lempeng Indo-Australia (Carlile dkk., 1990). Lempeng Eurasia bergerak ke arah selatan-tenggara, Lempeng Pasifik bergerak ke arah barat, dan Lempeng IndoAustralia bergerak kearah utara, sehingga Pulau Sulawesi memiliki empat buah lengan yang membentuk kesatuan mosaik geologi (Armstrong F. Sompotan, 2012). Pulau Sulawesi memiliki banyak sesar yang menyebabkan bercampurnya berbagai jenis batuan sehingga posisi stratigrafinya sangat kompleks dan rumit.

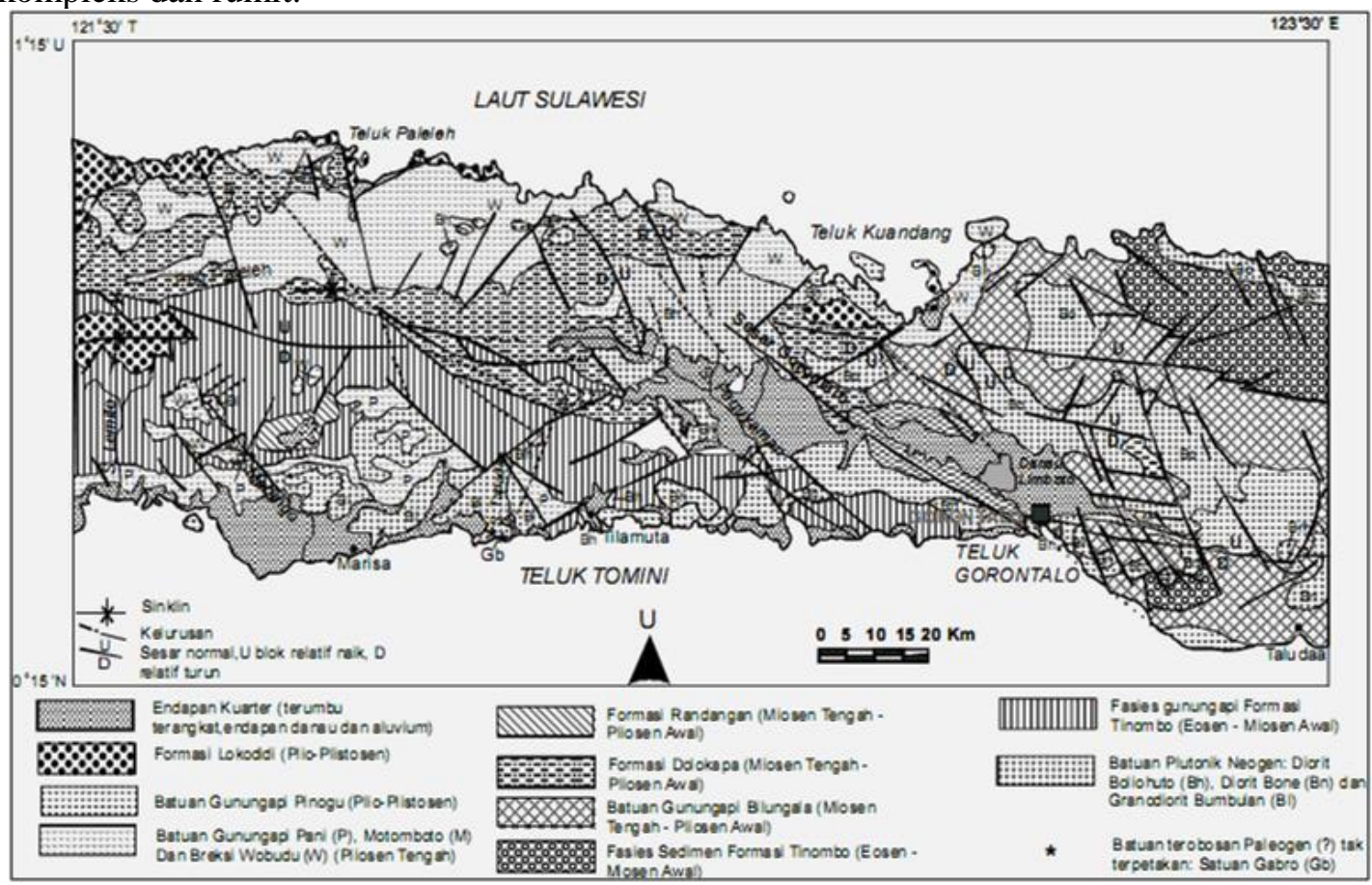

GAMBAR 4. Peta geologi Provonsi Gorontalo (Armstrong F. Sompotan, 2012)

Berdasarkan peta yang dihimpun dari peta geologi Tilamuta terlihat bawah lokasi kajian termasuk dalam Breksi Wobudu (Tmpv) yang tersusun oleh breksi vulkanik, tuf, dan lava andesit berumur Pliosen. Selain itu disekitar lokasi kajian terdapat Batuan Gunung Api Bilungula (Tmbv) dan Batuan Diorite Bone (Tmb). Batuan Gunung Api Bilungula (Tmbv) terdiri dari breksi, tuf, lava andesit. Diorite Bone (Tmb) berupa diorite yang menembus bagian bawah dari Batuan Gunung Api Bilungula. Hubungan antara Batuan Gunung Api Bilungula dan Breksi Wobudu adalah ketidakselarasan (unconformity) dimana Batuan Gunung Api Bilungula berumur lebih tua dari Breksi Wobudu. Terdapat sesar-sesar dengan arah timur laut-barat daya dan tenggara-barat laut. Sesar-sesar tersebut memungkinkan terdapat sesar-sesar minor di sekelilingnya (Thompson dan Turk, 1997).

\section{METODE RESISTIVITAS}

Survey metode resistivitas dilakukan untuk mengetahui persebaran resistivitas batuan di bawah permukaan tanah. Hal ini dilakukan dengan mengukur berdasarkan resistivitas sejati pada batuan 
dibawah permukaan tanah yang berhubungan dengan parameter geologis seperti porositas, kadar mineral, dan saturasi air dalam batuan. Survei geolistrik ini sudah sangat umum dipakai dalam ilmu pertambangan, hidrogeologi, maupun geoteknik. Terlebih lagi metode ini juga sudah mulai digunakan untuk survei dalam ilmu lingkungan.

Penetrasi yang didapat oleh metode resistivitas tidak dalam sehingga interpretasi yang dilakukan hanya dapat dilakukan untuk objek dengan kedalaman yang dangkal. Metode resistivitas dianggap cocok digunakan untuk investigasi Batuan Andesit dikarenakan lokasi dari cadangan Batuan Andesit cenderung dekat dengan permukaan atau dangkal. Batuan tersusun dari berbagai mineral dan mempunyai sifat kelistrikan yang berbeda-beda. Sifat kelistrikan batuan adalah karakteristik dari batuan dalam menghantarkan arus listrik. Batuan dapat dianggap sebagai medium listrik seperti pada kawat penghantar listrik, sehingga mempunyai tahanan jenis (resistivitas). Resistivitas batuan adalah hambatan dari batuan terhadap aliran listrik. Resistivitas batuan dipengaruhi oleh porositas, kadar air, dan mineral. Menurut Telford (1982), aliran arus listrik di dalam batuan dan mineral dapat digolongkan menjadi tiga macam, yaitu konduksi secara elektronik, konduksi secara elektrolitik, dan konduksi secara dielektrik.

Pemetaan nilai resistivitas sangat diperlukan untuk menentukan kedalaman dari Batuan Andesit yang akan digali dan batasan-batasan batuannya secara horizontal. Hal ini berguna agar ketika dilakukan penambangan lokasi yang direkomendasikan tepat sasaran. Nilai resistivitas dipengaruhi oleh beberapa faktor antara lain porosistas batuan, saturasi fluida, suhu dan salinitas serta tipe/kandungan mineral lempung yang terbentuk pada suatu lapisan yang merupakan faktor utamanya. Berdasarkan nilai resistivitasnya, maka batuan ataupun mineral di alam dibedakan menjadi 3 yaitu konduktor baik, konduktor sedang, dan isolator. Konduktor baik terjadi jika nilai resistivitasnya sangat kecil, berkisar antara $10^{-8}-1 \Omega \mathrm{m}$, contohnya metal (logam-logam), grafit, dan sulfida. Konduktor sedang terjadi jika nilai resistivitasnya $1-10^{7} \Omega \mathrm{m}$, contohnya beberapa oksida, ore, dan batuan porus yang mengandung air. Isolator terjadi jika tidak dapat mengalirkan arus listrik dan harga resistivitasnya sangat tinggi, lebih besar dari $10^{7} \Omega \mathrm{m}$. Batuan ini terdiri dari mineral silikat, fosfat, karbonat, dll. Berdasarkan data resistivitas telah diperoleh, dapat di ambil bahwa nilai resistivitas Batuan Andesit berada pada rentang 170 - $45000 \Omega \mathrm{m}$ sesuai TABEL 1.

Dalam praktiknya, metode resistivitas dilakukan dengan cara menginjeksikan arus listrik (I) ke dalam permukaan bumi dibantu dengan elektroda arus $(\mathrm{C} 1$ dan $\mathrm{C} 2)$ dan elektroda potensial (P1 dan P2) (GAMBAR 8). Hasil dari injeksi arus tersebut berupa beda tegangan (voltage) pada kedua elektroda potensial. Berdasarkan nilai arus (I) yang diinjeksikan dan beda tegangan (V) yang didapat, maka dapat diketahui resistivitas semu ( $\rho$ a) yang dihasilkan sebagaimana rumus berikut:

$$
P_{a}=k \frac{V}{I}=k R
$$

Dimana $\mathrm{k}$ adalah faktor geometri yang dihitung berdasarkan susunan elektroda yang digunakan. Sementara itu, $\mathrm{R}$ adalah nilai resistansi suatu batuan atau lapisan di bawah permukaan bumi. Hasil perhitungan $\rho$ a bukanlah nilai resistivitas sejati melainkan nilai resistivitas semu yang nilainya menganggap bahwa lapisan dibawah permukaan bumi adalah homogen, padahal pada kenyataannya tidaklah demikian. Mesikupun demikian, nilai ini dapat digunakan sebagai asumsi awal untuk membantu mendapatkan nilai resistivitas sejati di bawah permukaan bumi menggunakan program komputer yang kompleks. Nilai resistivitas material yang diukur tidak dapat langsung diperoleh di lapangan (Reynolds, 1997). Nilai resistivitas diperoleh setelah nilai resistensi (R) dan resistivitas semu ( $\rho$ a) dihitung terlebih dahulu. Resistensi merupakan nilai hambatan dari besaran beda potensial terhadap arus listrik tertentu (Serway dan Jewett, 2004).

Prosedur penyusunan elektroda pada konfigurasi dipol-dipol sedikit berbeda dengan prosedur penyusunan elektroda wenner, yaitu dengan memberikan variasi pada nilai " $n$ " dan "a" maupun kombinasinya pada jarak antar elektroda (seperti GAMBAR 9e). Metode konfigurasi dipol-dipol banyak digunakan karena pengaruh coupling elektromagnetik yang rendah terhadap sirkuit arus dan potensial. Konfigurasi ini sangat sensitif di area sekitar elektroda dan memiliki sebaran sensitivitas yang lebih vertikal dibandingkan metode wenner sehingga baik untuk mendeteksi perubahan resistivitas secara horizontal dan mencari informasi mengenai struktur geologis vertikal seperti dykes 
atau cavities. Kedalaman investigasi menggunakan konfigurasi dipol-dipol itu dipengaruhi oleh faktor "a" dan " $n$ " akan tetapi hasil investigasi konfigurasi ini tidak lebih dalam dari pada metode wenner.

Dipole-dipole ar ray

a).

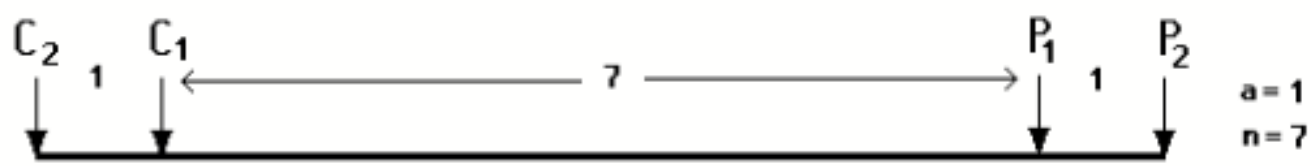

b).

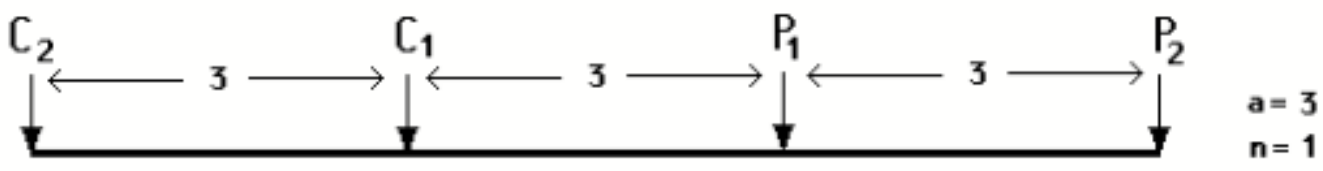

GAMBAR 5. Penyeimbangan faktor $n$ dan a pada metode dipol-dipol (Loke, 2000)

Kekurangan dari konfigurasi dipol-dipol adalah sinyal yang sangat lemah ketika nilai "n" semakin besar. Tegangan berbanding terbalik pangkat tiga n, yang berarti dengan kuat arus sama maka beda potensial yang terdeteksi menurun hingga 200 kali lipat saat $\mathrm{n}$ naik dari 1 ke 6 . Konfigurasi metode dipol-dipol sebagai berikut

$$
K=\pi n(1+n)(2+n) a
$$

TABEL 1. Nilai Resistivitas Batuan (Sumber: Suryono, 1978,; Telford, 1990; Loke, 2000; Milsom, 2003;

Telford et al, 2004; Lowrie, 2007; Kurniawan, 2011; Santoso, 2017)

\begin{tabular}{|l|c|l|c|}
\hline \multicolumn{1}{|c|}{$\begin{array}{c}\text { Rock or } \\
\text { sediment type }\end{array}$} & $\begin{array}{c}\text { Resistivity range } \\
(\mathbf{\Omega} . \boldsymbol{m})\end{array}$ & $\begin{array}{c}\text { Rock or } \\
\text { sediment type }\end{array}$ & $\begin{array}{c}\text { Resistivity range } \\
(\mathbf{\Omega} . \boldsymbol{m})\end{array}$ \\
\hline $\begin{array}{l}\text { Granite } \\
\text { porphyry }\end{array}$ & $\begin{array}{c}4,5 \times 10^{3}-1,3 \times \\
10^{6}\end{array}$ & $\begin{array}{l}\text { Quartzite } \\
\text { (various) }\end{array}$ & $10-2 \times 10^{8}$ \\
\hline $\begin{array}{l}\text { Feldspar } \\
\text { prophyry }\end{array}$ & $4 \times 10^{3}$ & $\begin{array}{l}\text { Consolidated } \\
\text { shales }\end{array}$ & $20-2 \times 10^{3}$ \\
\hline $\begin{array}{l}\text { Syenite } \\
\text { Diorite } \\
\text { porphyry }\end{array}$ & $1,9 \times 10^{3}-2,8 \times$ & Argilites & $10-8 \times 10^{2}$ \\
\hline Porphyrite & $10-5 \times 10^{4}$ & Sandstones & $1-6,4 \times 10^{8}$ \\
\hline $\begin{array}{l}\text { Carbonatized } \\
\text { porphyry }\end{array}$ & $2,5 \times 10^{3}-6 \times 10^{4}$ & Limestones & $50-10^{7}$ \\
\hline $\begin{array}{l}\text { Quartz diorite } \\
\text { Porphyry } \\
\text { (various) }\end{array}$ & $2 \times 10^{4}-2 \times 10^{6}$ & Dolomite & $3,5 \times 10^{2}-5 \times 10^{3}$ \\
\hline
\end{tabular}




\begin{tabular}{|c|c|c|c|}
\hline $\begin{array}{c}\text { Rock or } \\
\text { sediment type }\end{array}$ & $\begin{array}{c}\text { Resistivity range } \\
\text { (S.m) }\end{array}$ & $\begin{array}{c}\text { Rock or } \\
\text { sediment type }\end{array}$ & 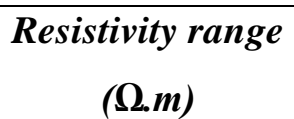 \\
\hline Dacite & $2 \times 10^{4}$ & Siltstone & $\begin{array}{c}1,5 \times 10^{4}-5,6 \times \\
10^{8}\end{array}$ \\
\hline Andesite & $\begin{array}{c}1,7 \times 10^{2}-4,5 \times \\
10^{4}\end{array}$ & $\begin{array}{l}\text { Graywacke } \\
\text { sandstone }\end{array}$ & $\begin{array}{c}4,7 \times 10^{3}-5,8 \times \\
10^{4}\end{array}$ \\
\hline $\begin{array}{l}\text { Diabase } \\
\text { (various) }\end{array}$ & $20-5 \times 10^{7}$ & $\begin{array}{l}\text { Arkosis } \\
\text { sandstone }\end{array}$ & $1,4 \times 10^{3}$ \\
\hline Lavas & $10^{2}-5 \times 10^{4}$ & $\begin{array}{l}\text { Organic } \\
\text { limestone }\end{array}$ & $0,6 \times 10^{3}$ \\
\hline Gabbro & $10^{3}-10^{6}$ & $\begin{array}{l}\text { Olivine } \\
\text { Pyroxene }\end{array}$ & $2 \times 10^{4}-5,6 \times 10^{7}$ \\
\hline Basalt & $10-1,3 \times 10^{7}$ & $\begin{array}{l}\text { Unconsolidated } \\
\text { wet clay }\end{array}$ & 20 \\
\hline Olivine norite & $10^{3}-6 \times 10^{4}$ & Marls & $3-70$ \\
\hline Peridotite & $3 \times 10^{3}-6,5 \times 10^{3}$ & Clays & $1-10^{2}$ \\
\hline $\begin{array}{l}\text { Breksi, Breksi } \\
\text { Vulkanik, } \\
\text { Aglomerat }\end{array}$ & $80-1700$ & Breksi Tuf & $25-80$ \\
\hline Tuf & $10-200$ & Air & $\sim$ \\
\hline
\end{tabular}

\section{KONSEP KERJA SOFTWARE RES2DINV}

Pada proses pelaksanaan survei geolistrik, instrumen yang tersedia secara komersial akan mengukur hambatan dan mengkonversi data survei tersebut menjadi nilai resistivitas semu. Konversi data ini dilakukan menggunakan aplikasi komputer yang tersedia bersama alat survei. Proses konversi data resistivitas semu menjadi model resistivitas untuk keperluan interpretasi geologis memerlukan proses tersendiri. Umumnya model 2D yang digunakan merupakan model bawah permukaan bumi yang terdiri atas persegi-persegi kecil dalam jumlah banyak. Kemudian program komputer digunakan untuk menentukan nilai resistivitas tiap persegi sehingga sesuai dengan hasil pengukuran resistivitas semu yang diperoleh. Aplikasi RES2DINV.EXE memetakan bawah permukaan bumi menjadi sejumlah persegi untuk kemudian diolah dengan inversi least-square dalam menghitung rasistivitas setiap kotak tersebut.

Pada aplikasinya, program RES2DINV banyak digunakan oleh SDM yang tidak familiar terhadap teori inversi. Pada kenyataannya, aplikasi ini dibuat untuk bekerja otomatis sebisa mungkin sehingga hanya sedikit data yang perlu dimasukkan secara manual. Aplikasi RES2DINV memiliki beberapa parameter yang sudah diasumsikan dalam melakukan proses inversi. Umumnya nilai-nilai umum tersebut memberikan hasil yang cukup sesuai, akan tetapi terdapat beberapa parameter yang dapat diatur ulang secara manual untuk meningkatkan akurasi hasil inversi. 


\section{KONSEP KERJA SOFTWARE ROCKWORKS}

Merupakan software yang dikembangkan oleh RockWare Inc. Software ini dapat digunakan untuk membuat model 3D menggunakan data koordinat $\mathrm{X}, \mathrm{Y}$ dan $\mathrm{Z}$ disertai dengan nilai/Grade yang bersesuaian (data XYZG). Dalam eksplorasi resistivity, koordinat X dan Y didokumentasikan menggunakan (alat). Sementara koordinat $Z$ (elevasi) dan G (true resistivity) diperoleh melalui pengolahan data dan pemetaan 2 Dimensi menggunakan aplikasi RES2DINV. Prinsip kerja Rockworks dalam membentuk model 3D adalah memetakan data-data XYZG yang diinput menggunakan pilihan algoritma yang sesuai dan penyaringan data sesuai dengan kebutuhan. Data yang dibaca pada RockWorks akan ditampilkan sebagai voxel-voxel data di mana voxel ini merupakan unit volume terkecil dalam model 3D yang dihasilkan yang mewakili nilai $\mathrm{X}, \mathrm{Y}, \mathrm{Z}$ dan $\mathrm{G}$ tertentu.

Proses solid modelling merupakan proses grid 3 dimensi untuk menghasilkan susunan 3 dimensi dari voxel-voxel dengan spasi regular dari data-data dengan spasi irregular. Dengan mengetahui nilai X, Y dan Z, algoritma RockWorks 15 dapat menginterpolasikan nilai-nilai terukur (G) seluas project area. Adapun nilai terukur ini dapat berupa geokimia, geofisika bahkan tipe litologi bawah tanah. Terdapat beberapa jenis algoritma dan model yang bisa diproses dalam RockWorks 15 , yakni sebagai berikut:

- Horizontal Lithoblending : Ini merupakan algoritma yang dibuat untuk memetakan model litologi. Algoritma ini menempatkan voxel dengan melihat keluar secara horizontal dari setiap borehole mencari lingkaran-lingkaran diameter yang bertambah. Mulanya agoritma ini menempatkan voxel di sekitar setiap borehole. Kemudian algoritma akan bekerja keluar arah borehole voxel demi voxel dan menempatkan "lingkaran" berikutnya yang secara efektif mengkategorikan litologi secara horizontal keluar dari tiap borehole.

- Closest Point : Ini merupakan metode modelling paling mendasar di mana nilai voxel disetel sama dengan nilai titik data terdekat. Kekurangan model ini adalah bisa menyebabkan model yang dihasilkan kurang baik jika jumlah data sedikit/kurang memadai.

- Inverse Distance : Metode ini menempatkan nilai voxel berdasarkan rata-rata augmentasi dari titik-titik data sekitar, antara seluruh titik disekitar atau pada arah tertentu, menggunakan komponen augmentasi variabel atau tetap.

o Isotropic : program ini menggunakan semua titik data yang tersedia ketika menghitung nilai voxel, sehingga berguna ketika memodelkan distribusi data yang seragam di lingkungan stratiform. Kekurangan model ini adalah data tinggi terkonsentrasi di sekitar borehole.

o Anisotropic : Pada algoritma ini, untuk pemodelan dicari titik-titik terdekat di setiap sector 90 derajat sekitar voxel, bukan seluruh data. Metode ini cocok untuk modelling drill-hole berdasarkan data deposit stratiform. Pada metode ini cenderung menghubungkan nilai tinggi dan rendah pada elevasi yang sama.

o Weighting : Menggunakan seluruh titik data, tetapi memberatkan secara berbeda berdasarkan horizontal v. posisi vertical voxel. Berguna untuk mengendalikan lenticularity model.

- Horizontal Biasing : metode ini berfungsi seperti metode inverse distance, tetapi metode ini memungkinkan definisi jarak vertical antar voxel melebihi titik sehingga tidak bisa digunakan untuk menentukan nilai voxel.

\section{METODOLOGI}

Penelitian ini dilakukan di Laboratorium Geofisika, Fakultas Matematika dan Ilmu Pengetahuan Alam, Universitas Indonesia. Penelitian ini dilakukan selama periode 25 Maret hingga Juni 2019. Penelitian menggunakan data hasil survei geolistrik di Provinsi Gorontalo, Indonesia. Sebaran titik pengukuran geolistrik diusahakan dapat mewakili daerah survei, sehingga informasi yang diperoleh dapat memberikan deskripsi yang lengkap tentang daerah survei. Secara umum, penelitian ini menitikberatkan pada pengolahan data resistivitas yang dilakukan pada 3 tahap, yaitu 
persiapan, pelaksanaan, dan evaluasi. Ketiga tahap ini memiliki proses berbeda. Tahap-tahapannya adalah sebagai berikut:

1. Persiapan : studi literatur.

2. Pelaksanaan : pengolahan data resistivitas menggunakan software RES2DINV, exterminate bad datum, least squeare inversi, iterasi, pemodelan 2D dan 3D.

3. Evaluasi : interpretasi zona Batuan Andesit, dan menghitung volume cadangan Batuan Andesit.



GAMBAR 6. Diagram alur penelitian

Dari data resistivitas yang didapat, kemudian diolah menggunakan software RES2DINV. Data output dari pengolahan menggunakan software RES2DINV akan didapatkan model persebaran nilai resistivitas 2 dimensi di bawah permukaan tanah. Kemudian, data resistivitas diolah kembali hinnga menjadi berupa model interpolasi 3 dimensi menggunakan software Rockwoks. Selanjutnya adalah intrepetasi dan menganalisis data resistivitas guna menentukan dan membedakan antara zona Batuan Andesit dengan batuan lainnya. Langkah selanjutnya adalah menghitung volume Batuan Andesit. Diagram alur penelitian dapat dilihat pada GAMBAR 6.

\section{HASIL DAN PEMBAHASAN}

Berdasarkan hasil dari pengolahan data resistivitas di lapangan "A" sebanyak 15 lintasan yang telah dilakukan dari tahap proses inversi hingga menjadi model 2D diperoleh model bawah permukaan ditunjukan pada GAMBAR 7. Identifikasi Batuan Andesit di lokasi "A" dilakukan berdasarkan interpretasi nilai dan pola distribusi resistivitas hasil pemodelan pada lintasan 1 hingga 
lintasan 15. Nilai resistivitas yang dijadikan acuan untuk interpretasi mengacu pada TABEL 1. Batuan Andesit di lokasi kajian memiliki nilai resistivitas yang lebih tinggi dari batuan yang lainnya. Hal tersebut dikarenakan Batuan Andesit lebih resisten terhadap deformasi oleh gaya tektonik dan pelapukan. Terdapatnya struktur di sekitar lokasi kajian memungkinkan terbentuknya retakan pada batuan yang kurang resisten. Zona retakan tersebut akan menjadi zona bagi terjadinya pelapukan, pembentukan mineral lempung, serta ruang bagi airtanah dimana faktor-faktor tersebut menyebabkan menurunnya nilai resistivitas material dan terbentuknya pola resistivitas yang tidak beraturan.

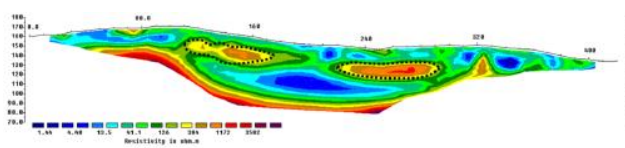

(a)

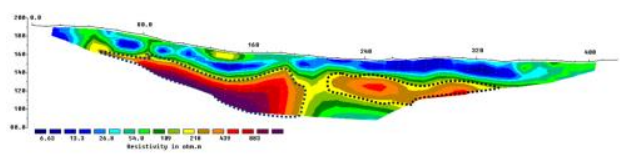

(c)

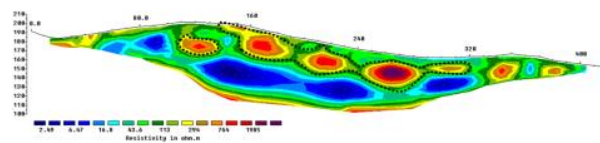

(e)

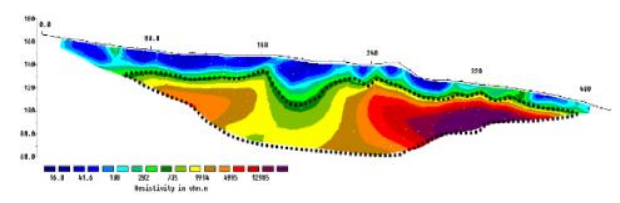

(g)



(i)

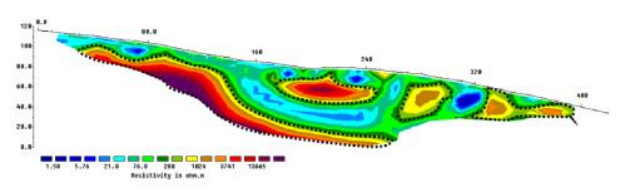

(k)

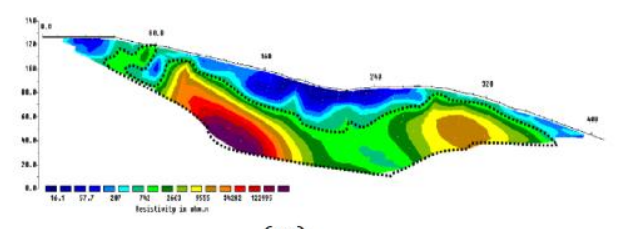

(m)

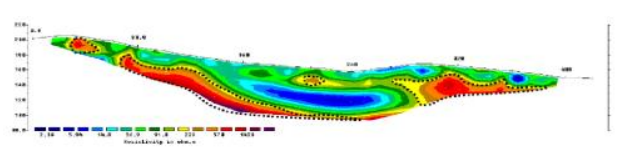

(b)

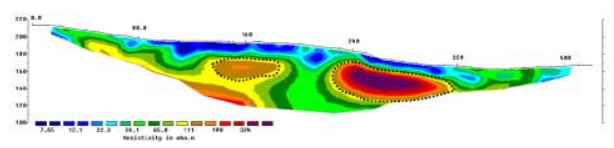

(d)

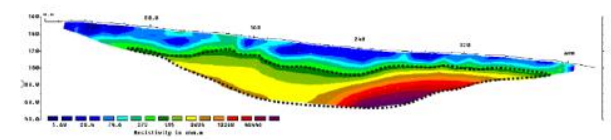

(f)

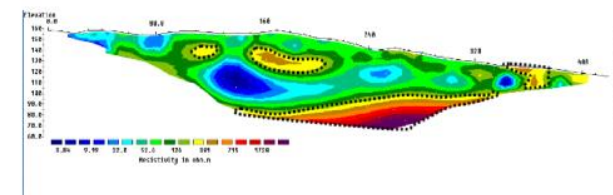

(h)

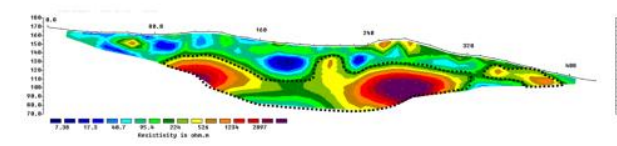

(j)

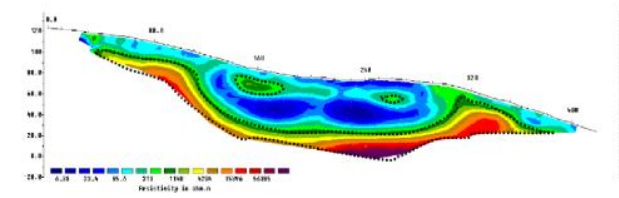

(l)

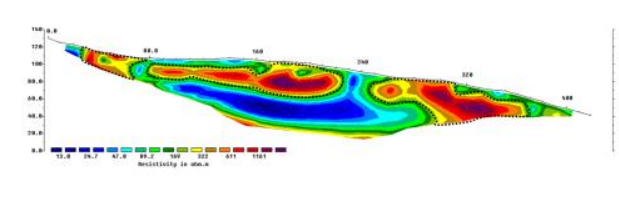

(n)

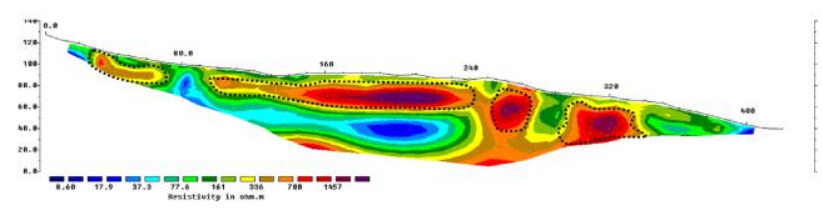

(o)

GAMBAR 7. Model 2 dimensi pada 15 lintasan 




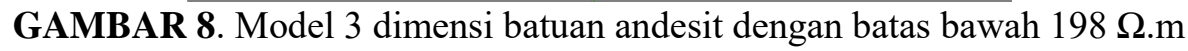

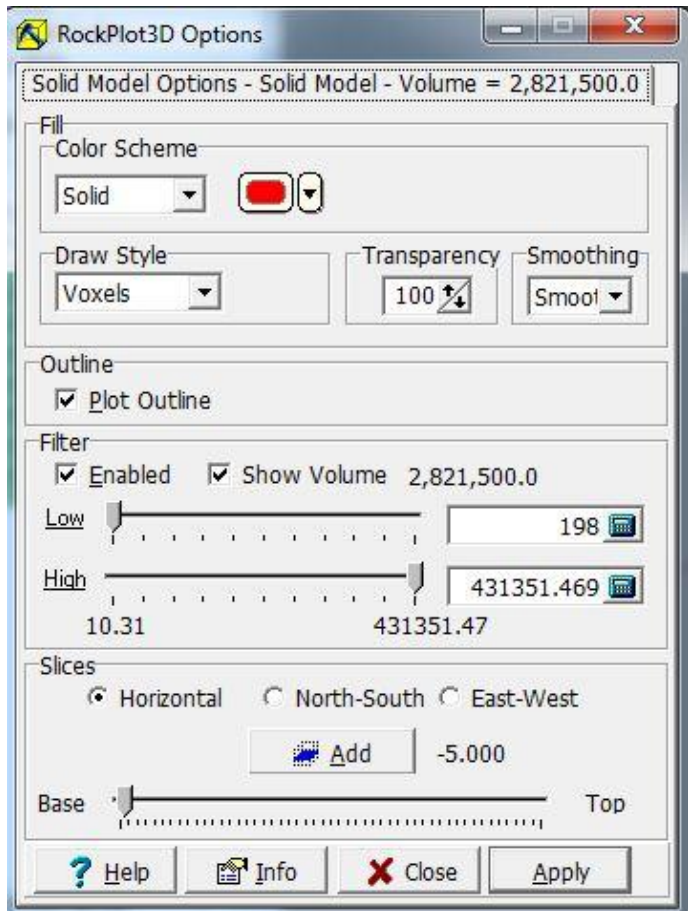

GAMBAR 9. Penghitungan volume melalui Rockworks pada batas nilai resistivitas terendah andesit sebesar $198 \Omega$. M.

\section{SIMPULAN}

Berdasarkan hasil pemodelan 2 dimensi dan 3 dimensi serta perhitungan volume cadangan bahan galian tambang di lokasi "A", serta mempertimbangkan rumusan masalah dan tujuan, maka dapat ditarik kesimpulan sebagai berikut:

1. Cara memodelkan daerah prospek cadangan tambang andesit yaitu dengan menggunakan software RES2DINV dengan mempertimbangkan nilai resistivitas. Berdasarkan pemodelan menunjukkan terdapat kenampakan pola distribusi resistivitas yang diperkirakan sebagai cadangan Batuan Andesit.

2. Identifikasi Batuan andesit di lapangan "A" dilakukan dengan melihat kisaran nilai resistivitas yang berkisar dari $198 \Omega . \mathrm{m}$.

3. Volume Batuan Andesit di lapangan "A" dapat dihitung dengan pemodelan data inversi RES2DINV dan interpolasi Rockworks sehingga diperoleh hasil volume sebesar berkisar $4.084 .375 \mathrm{~m} 3$ dengan nilai batas bawah resistivitas Batuan Andesit terendah sebesar 198 $\Omega . \mathrm{m}$. 


\section{REFERENSI}

[1] Badan Pusat Statistik. Proyeksi Penduduk Menurut Provinsi, 2010-2035 (Ribuan). Jakarta: Badan Pusat Statistik, 2013.

[2] Badan Pusat Statistik. Gorontalo Dalam Angka 2018. Jakarta: Badan Pusat Statistik, 2018.

[3] Badan Pusat Statistik. Proyeksi Penduduk Menurut Provinsi, 2010-2035 (Ribuan). Jakarta: Badan Pusat Statistik, 2013.

[4] Bahri, Sukido Dan N. Ratman. Peta Geologi Lembar Tilamuta, Sulawesi. Bandung: Pusat Penelitian Dan Pengembangan Geologi, 1993.

[5] Blatt, Harvey, Dan Robert J. Tracy. Petrology. Freeman. Isbn 0-7167-2438-3. 1996.

[6] Carlile, J.C., Digdowirogo, S. \& Darius, K. Geological Setting, Characteristics And Regional Exploration For Gold In The Volcanic Arcs Of North Sulawesi, Indonesia. Journal Of Geochemical Exploration, 35:105-140, 1990.

[7] Daniels, F. And Alberty,R.A. Physical Chemistry, John Wiley \& Sons,Inc. 1966.

[8] Dobrin Milton B., Dan Savit Carl H., Introduction To Geophysical Prospecing Ed. 4th, Singapura: Mcgraw-Hill International Edition, 1988.

[9] Hall, R. \& Wilson, M. E. J., Neogene Sutures In Eastern Indonesia. Journal Of Asian Earth Sciences, 18, 781-808, 2000.

[10] Keller,G.V.And Frischknecht,F.C. Electrical Methods In Geophysical Prospecting. Oxford: Pergamon Press Inc, 1966.

[11] Kurniawan, Alva. Identifikasi Struktur Bedding Bentuklahan Berdasarkan Metode Ert Konfigurasi Double Dipole Di Bukit Gunungsari Kecamatan Salam Kabupaten Magelang. Yogyakarta: Universitas Gadjah Mada, 2011.

[12] Kurniawan, Alva. Kajian Genesis Perbukitan Gendol Di Daerag Muntilan-Salam, Kabupaten Magelang, Jawa Tengah. Yogyakarta: Universitas Gadjah Mada, 2016.

[13] Loke, M.H. Electrical Imaging Survey For Environmental And Engineering Studies, 2000.

[14] Loke, M.H. Res2dinv Ver. 3.53 Manual. Geotomo Software. 2003.

[15] Lowrie, W. Fundamentals Of Geophysics, 2nd Edition. Cambridge: Cambridge University Press, 2007.

[16] Mcdowell, P.W., R.D. Barker, A.P. Butcher, M.G. Chulsaw, P.D. Jackson, D.M. Mccann, B.O. Skipp, S.L. Matthews, \& J.C.R. Arthur. Geophysics In Engineering Investigation. London: Ciria, 2002.

[17] Milsom, J. Field Geophysics, The Geological Field Guide Series 3rd Edition. West Sussex: John Wiley \& Sons, 2003.

[18] Nuryati, Dan Faradila, A. Statistik Pertambangan Bahan Galian Indonesia 2011-2015 (The Indonesia Quarrying Statistics). Jakarta: Badan Pusat Statistik, 2016.

[19] Raghel Yunginger, La Ode Ngkoimani, Dan Ahmad Zinuri. Laporan Akhir Tahun Pertama Hibah Penelitian Kerja Sama Antar Peguruan Tinggi (Hibah Pekerti). Universitas Negeri Gorontalo, 2011.

[20] Reynold, J.M. An Introduction To Appllied And Enviromental Geophysics. New York: Jhon Wiley \& Sons, Ltd, 1997.

[21] Rockworks. Tutorial Rockworks 2006 Rev. 2008. Rockware Incorporation, 2006. 
[22] Santoso, D. Pengantar Teknik Geofisika. Bandung: Institut Teknologi Bandung, 2002.

[23] Santoso, Andyono B. Dan Sidiq Hidayatullah. Perhitungan Sumberdaya Batuan Breksi Andesit Berdasarkan Ukuran Fragmen Dengan Menggunakan Metode Geolostrik (Studi Kasus Lahan 52, Desa Mekarsari, Kecamatan Merak, Kabupaten Cilegon, Provinsi Banten. Issn:2477-7870, 2017.

[24] Serway, R.A., \& J.W. Jewett. Physics For Scientist And Engineers, 6th Edition. Pomona: Thomson Brooks/Cole, 2004.

[25] Sompotan, Armstrong F. Struktur Geologi Sulawesi. Bandung: Perpustakaan Sains Kebumian Institut Teknologi Bandung, 2012.

[26] Suyanto, I., Dan Utomo A. S. Analisis Data Resistivitas Dipol-Dipol Untuk Identifikasi Dan Peprhitungan Sumber Daya Asbuton Di Daerah Kabungka, Pasarwajo, Pulau Buton, Sulawesi Tenggara. Jurnal Fisika Indonesia, 17 (50), 2014, pp. 1-7,

[27] Telford, W.M., L.P. Geldart, R.E. Sheriff, Dan D.A. Keys. Applied Geophysics. New York: Cambridge University Press, 1990.

[28] Thompson, G.R., \& J. Turk. Introduction To Physical Geology. Fort Worth: Saunders College Publishing, 1997.

[29] Van Leeuwen, T.M. 25 Years Of Mineral Exploration And Discovery In Indonesia. Journal Of Geochemical Exploration, 50, 1994, pp.13-90. 
